\author{
Robert Hodel \\ Univerzitet u Hamburgu, Institut za slavistiku \\ fs8a023@uni-hamburg.de \\ Robert Hodel \\ Universität Hamburg, Institut für Slavistik \\ fs8a023@uni-hamburg.de
}

\title{
STIHOVNA FORMA. KOMPARATIVNI POGLED NA RUSKU LIRIKU 20. VIJEKA ${ }^{1}$
}

\section{VERSE FORM. COMPARATIVE VIEW WITH THE RUSSIAN LYRIC OF THE 20 $0^{\text {TH }}$ CENTURY}

Rad koji slijedi posvećen je pitanju, zašto se vezani stih u Rusiji za razliku od ostatka Evrope kao i Amerike, održao tokom cijelog 20. vijeka kao dominantna stihovna forma. Pri tome ćemo u prvom koraku uporediti razvoj ruskog pjesništva sa njemačkim, poljskim i srpskim, a u drugom koraku ćemo diskutovati jezičke, estetske i političke razloge ovih razlika.

Ključne riječi: vezani stih, slobodni stih, lingvistika stiha, razvoj stihovne forme, ruska poezija, srpska poezija, njemačka poezija, polska poezija.

The following paper focuses on question why, unlike in the rest of Europe and the United States, formal verse in Russia endured throughout the entire $20^{\text {th }}$ century as dominant verse form. Firstly, we will compare the development of Russian poetry to the German, Polish and Serbian, and then we will discuss linguistic, esthetical, and political causes of these differences.

Keywords: formal verse, free verse, verse linguistic, verse form development, Russian poetry, Serbian poetry, German poetry, Polish poetry.

\section{Razvoj versifikacije u 20 . vijeku}

\subsection{O ruskom stihu 20-og vijeka}

Nakon što se u 18. i 19. vijeku na cijelom ruskom govornom području razvila silabotonika, u „srebrnom dobu“, koje Gasparov (2000: 307) situira u vrijeme od 1890-1935, „nesilabotonički eksperimenti“ (несиллаботонические экспери-

1 Preveo Sead Porobić 
менты) dosežu i do 20\% ukupnog pjesništva. Pri tome velika većina ovih eksperimenata otpada na tonsku metriku, a slobodni stih, kome se posvećuju autori poput Bloka, Gipiusa, Sologuba, Kamenskog, Hljebnikova, Gurova, Kručeniha... te sporadično i predstavnici ,proleterskih pjesnika“ (Orlicki 1995), ostaje marginalna pojava. Ovo vrijedi još više za prvu fazu sovjetskog stiha, tj. za 20 -te i rane 30-te godine:

После полосы экспериментов около 1920 г. (не только у Есенина или Хлебникова, но и у пролетарских поэтов) он почти начисто исчезает из употребления. Маяковский обращается к нему лишь однажды („1-е Мая“, 1923) (Gasparov 2000: 282).

I sama tonika, koja u razdoblju od 1925-1935 narasta do skoro jedne četvrtine svih stihova, pokazuje u ovim godinama već neko drugo lice:

[...] большая часть ее - дольники, которые ближе всего к силлаботонике, ритм акцентного стиха становится строже и проще, из него выделяется даже переходная форма к дольникам - тактовик конструктивистов (Isto: 304).

U drugoj fazi sovjetskog pjesništva, 1935-1955, orijentišu se autori ponovo na klasične uzore 19-og vijeka, naročito na Puškina, tako da nesilabotonički stihovi sada čine tek $12 \%$ (isto: 307 ). Slobodni stih ne igra sada skoro nikakvu ulogu, čak ni u prevodima:

Переводя верлибры прогрессивных зарубежных поэтов (Арагона, П. Неруды), переводчики 1940-х гг. то и дело привносят в них ритм и даже рифму (isto, s. 282).

Tek u trećoj fazi sovjetskog stiha, u toku Hruščovljevog doba „otapanja“, kada zapaženi pjesnici sve učestalije prevode slobodne stihove, mijenja se situacija iznova:

$<\ldots$..> три четверти поэтов 1960-1970-х гг. хотя бы раз или два обращались к верлибру, но лишь немногие писали им систематически. В целом в это время на свободный стих приходится около $10 \%$ всех неклассических примеров - больше чем на акцентный стих (isto: 283).

Bez obzira na ove nove pojave ostaju ovi nesilabotonički eksperimenti tokom cijelog sovjetskog doba ipak sekundarna pojava:

<..> в пору социалистического классицизма 1935-1980 гг. они стабилизируются на $12 \%$ (этот уровень одинаков и в сталинское время, и в хрущевскоепослехрущевское, когда, как известно, некоторым экспортным поэтам вроде Евтушенко и Вознесенского с их подражателями было позволено экспериментировать шире) (isto: 307$)$.

Čak i u postsovjetskoj Rusiji mijenja se situacija tek sasvim lagano, kako to pokazuje Gasparovljeva analiza šest ideološki i poetološki različitih časopisa iz 1997-e godine (Новый мир, Знамя, Москва, Наш современник, Новая юность, Арион). U prosjeku raste neklasični metar (неклассические размеры) ponovo na $20 \%$, pri čemu raspodjela ide od 3,5\% (Нам современник) do 28\% (Арион). 
Ovdje na „strogi dioni stih“ (строгий дольник) otpada podjednako kao i na slobodni stih (вольный верлибр), naime 35-40 \% nesilabotoničkih stihova (не-силлаботоники, isto: 308$)$.

Ova narastajuća tendencija slobodnog stiha pojačava se i u 21. vijeku, kako proizilazi iz mog sopstvenog iskustva stečenog u dvama antologijama (sa ukupno 60 pjesnika): Dok kod pjesnika rođenih između 1940-1960 (Antologija I, Hodel 2015) silabotonika još uvijek dominira i samo se pojedinačni autori konzekventno posvećuju slobodnom stihu, kod godišta 1960-1980 piše već većina pjesnika (Antologija II, Hodel 2019) u značajno većem omjeru (a djelimično i pretežno) slobodnim stihom. Još jasnije se ova tendencija pokazuje u sljedećoj generaciji „rođenih od sredine 1980-tih do 1990-tih godina“, odnosno onih koji se ,javljaju u 2010-tim“. Međutim bez obzira na to i u 21-om vijeku metrički vezani stih ostaje u Rusiji važnom opcijom, koja ni u kom slučaju nije reducirana na funkciju ritmičke reminiscencije ili pak ironizacije. Čak je suprotna stvar u pitanju. Tako Davidov (2013) piše: „Проблема, собственно, заключается в особой, внестиховой маркированности верлибра в культурной среде.“

\subsection{Razvoj njemačkog slobodnog stiha}

Po Wagenknechtu (2007: 117-119) uvodi Friedrich G. Klopstock, oslanjajući se na antički metar oda, sredinom 18 . vijeka ,slobodne ritmove“ 2 u njemačko pjesništvo. Njih preuzimaju pjesnici epohe Sturm und Drang (prije svih mladi Goethe), Friedrich Hölderlin i Heinrich Heine, koji počinju da razgrađuju svoj antički stil, razvijajuće ga dalje, da bi ih Detlev von Liliencron i Arno Holz konačno odvojili od njihove vezanosti na klasične uzore. Time oni otvaraju pjesnicima ekspresionizma „mogućnost, da pišu stihove, koji metrički uopšte nisu povezani“ (isto: 125 ).

Razvoj ka slobodnom stihu ne odvija se, naravno, ni u kom slučaju pravolinijski i prije svega ne može ga se shvatiti isključivo na nacionalnoj osnovi. Važni izvori njemačkog slobodnog stiha su nerimovani dugi stih Walt Whitmana (Leaves of Grass), koga je Jules Laforgue 1886. prvi put preveo za francuski časopis La Vogue i koji je skupa sa vers libéréom ${ }^{3}$ simbolista (Charles Baudelaire, Paul Verlaine, Arthur Rimbaud, Stéphane Mallarmé) uticao na razvoj francuskog slobodnog stiha (vers libre). T. E. Hulme i F. S. Flint predstavljaju francuske verslibriste 1909. u londonskom Poets Club-u, koji će kasnije postati rasadište angloameričkog imažinizma (Imagismus), koji će opet sa svoje strane izvršiti uticaj na razvoj T. S. Eliota, Ezre Pounda ili Amy Lowell. Time je, razumije se, pomenut samo jedan o mnogih razvojnih pravaca: Slobodni stih je rezultat jedne internacionalne mreže pjesnika i kritičara. O uticaju francuskog vers libre-a na nje-

2 Slobodni ritmovi (Freie Rhythmen) su doduše metrički nepovezani i nerimovani, imaju međutim naspram slobodnih stihova moderne jednu izraženu ritmiku i najčešće uzvišeniji ton. Prelaz između ovih dvaju formi je doduše vrlo fluidan.

3 Slobodni («Oslobođeni») stih (vers libéré) je obilježen labavljenjem metričkih pravila (npr. promjenljivim brojem slogova i pokretljivom cezurom). 
mačku liriku svjedoči primjerice već pjesma Stefana Georga „Hochsommer“ (Kasno ljeto, 1890; Breuer 1991: 262).

Wagenknecht (2007: 124-125) dovodi ovaj proces u nadređeni odnos opšteg odvajanja moderne od tradicije, a taj odnos se osim slobodnim stihom iskazuje još i u novom jeziku forme - npr. u napuštanju stroge forme strofa u sonetu (Bertolt Brecht) ili u velikoj dužini stihova, koja rimu gura u drugi plan (Ernst Stadler, Franz Werfel, Brecht). Breuer (1991: 231, 247) u ovom napuštanju ističe posebnu važnost Friedricha Nietzschea, čiji se tekst ,prevrednovanje svih vrijednosti“ („Umwertung aller Werte“) odnosi i na vezane, čvrste forme pjesništva. Već u zimu 1884/85 (Pismo Carlu Fuchsu) Nietzsche ističe „poskakivanje iktusa“ („Hopsass des Iktus“) u njemačkom pjesničkom jeziku nasuprot antičkog kvantitetskog pjesništva. A 1888. on piše Fuchsu: „Te dvije vrste ritma su oprečne u svojoj iskonskoj namjeri i porijeklu. Naša barbarska (ili germanska) ritmika pod ritmom razumije slijed istih jakih afektivnih uzlaza (Affekt-Steigerungen), koji su rastavljeni slabim mjestima-padanjima (Senkungen). [...] Naš ritam je Sredstvo izražavanja afekta: antički ritam, vremenski ritam ima nasuprot tome zadaću, da afekt obuzda i da ga do izvjesne mjere eliminiše“ (Nietzsche 1960, III: 1315).

Iz ovoga Breuer (1991: 235) objašnjava i zašto Nietzsche ne pravi osnovnu razliku između proze i poezije.

Kada autori, kao što su Stefan George, Hugo von Hofmannsthal, Rainera Maria Rilke, Rudolfa Borchardt, i dalje pišu u okviru klasično-romantične „Summa metrica“, to Breuer (isto: 258) tumači kao eksperimentisanje sa sviješću o formi koja neminovno ide svom kraju. Za Breuera (isto: 291) i u artificijelnom traženju forme ekspresionista počiva ,dezorijentisanost i disocijacija lirskog subjekta" koja oslobađanjem od tradicionalnih formi sebi konačno krči put. Naravno da time silabotonika još uvijek nije postala marginalna pojava. Zbirke poezije $s$ kraja 40-tih i početka pedesetih godina su još uvijek snažno orijentisane ka čvrstim poetskim formama antičkog i romanskog porijekla (Günter Eich, Peter Huchel, Paul Celan), tek tokom pedesetih godina napuštaju ovi autori strogu formu i suprotstavljaju se decidirano „vladajućim jezičkim i komunikacijskim očekivanjima“" (isto: 372).

Za daljnji razvoj poetskog jezika poslije 1965. u odnosu na „bečku glasovnu poeziju“ („Wiener Lautpoesie“), „,berlinski kasni nadrealizam“, „happening-forme" (up. recitiranje glasovne poezije Ernsta Jandla), agitatorsku poeziju i njenu „anti-vrstu“ „,nove subjektivnosti““ (Nicolas Born, F. C. Delius, Michael Krüger, Johannes Schenk, Jürgen Theobaldy, Roman Ritter) ili daljnjeg razvijanja brechtovskog modela u DDR-u (isto: 397-401) može se kao predstavnik navesti manifest Eugena Gomringera „od stiha ka konstelaciji“ (1954). Pjesnik „konkretne poezije“ zahtjeva s obzirom na sve veću raširenost ekonomske racionalnosti, koja (sa svoje strane) vodi ka formalnom pojednostavljivanju jezika, aktualiziranje poetskih formi: ,[...] pjesma u stihovnoj formi je ili historijska veličina ili je, ako je i dan danas aktuelna, umjetničko-zanatlijska reminiscencija. Stih nije više živuće načelo reda jezika, njegov poseban jezik je odvojen od jezika stvarnog života“" (Gomringer 1972: 154). 


\subsection{O situaciji u poljskom i u srpskom}

Razvoj slobodnog stiha, kakav se pokazuje u književnosti na njemačkom govornom području, odslikava se u grubim crtama i u silabički označenoj situaciji na poljskom. Još u doba Mlade Poljske tzv. nepravilni stih (wiersz nieregularny), kojeg se može pratiti unazad sve do baroka, u pojedinačnim slučajevima, prije svih kod Stanisława Wyspiańskog, prelazi u jedan slobodni stih (wiersz wolny, Pszczołowska 2001: 301), da bi u krakovskoj avangardi (Awangarda krakowska) sa Tadeuszom Peiperom, Julianom Przybośem i Janom Brzękowskim doživio svoj prvi sistematski razvoj (isto: 346 ). Za prvu polovicu 20. vijeka piše Pszczołowska (isto: 355):

Dla ostatniego 50-lecia w dziejach wersyfikacji najbardziej znamiennym zjawiskiem jest coraz większa rola wiersza wolnego, a co za tym idzie — wypieranie wiersza metrycznego $<\ldots>$ wiersz wolny dominuje, wiersz metryczny jest formacją nacechowaną $<\ldots>$

Za drugu polovicu 20. vijeka najvažniji fenomen jeste narastajuća uloga slobodnog stiha, a sa njom blijedi i važnost metričkog stiha < ..> slobodni stih dominira, metrički stih je markirana formacija $<$... $>$.

Ništa manje ambiciozno ne sprovodi se ni oslobađanje od silabičke tradicije u srpskoj književnosti, koja se u 20. vijeku mora posmatrati kao dio cjelokupnog štokavskog 4 jezičkog i kulturnog prostora.

Slobodni stih koji je sa Vojislavom Ilićem, Silvijem Strahimirom Kranjčevićem, Lazom Kostićem Miletom Jakšićem već u 19. vijeku dosegao izvjesnu poziciju (up. Škreb/Stamać 1986: 323), dobija nove impulse preko prevoda u časopisu Bosanska vila (među ostalima i Leaves of Grass Walta Whitmana) i postaje još prije Prvog svjetskog rata pjesnički program, naročito ga je formulisao i praktikovao Svetislav Stefanović. Kao važan preteča vrijedi i 1906-e objavljena zbirka pjesama „Pesme“ Milana Ćurčina. Za simboliste-parnasovce, međutim, koji u ovo vrijeme pišu ne samo silabičke nego i silabičko-tonske stihove, ostaje slobodni stih još uvijek marginalni fenomen. Tako ga npr. Jovan Dučić uopšte ne koristi, izuzev pjesama u prozi, a Aleksa Šantić piše konačno samo 11 pjesama u slobodnom stihu od ukupno 606 pjesama (Porobić 2010: 436). Nakon Prvog svjetskog rata, doduše, sa generacijom pjesnika poput Antuna Branka Šimića, Ive Andrića, Miroslava Krleže, Miloša Crnjanskog ili Rastka Petrovića, nameće se slobodni stih u svoj svojoj širini.

Ovu dominantnu poziciju od tada pa do danas slobodni stih nije izgubio na cjelokupnom štokavskom govornom području. Kao ilustracija mogu poslužiti dvije antologije koje su objavljene 2011. Deset deka duše (Hodel 2011) objedinjuje 28 srpskih autora rođenih između 1940-1960. Od svih tih autora samo pojedini pišu, i samo u određenim tekstovima, vezanim stihom. I ako je to slučaj,

${ }^{4}$ Za policentrični jezički sistem koji se nekada nazivao „srpskohrvatski“ koristimo pojam „štokavski““. 
onda se njihov silabički metar (rjeđe silabičkotonski) pojavljuje kao markiran, tj. kao nosilac neke određene funkcije, naročito su u pitanju: ironizacija (Milan Milišić: „Stari Grci“, Đorđe Sladoje: „Pokuda zavičaju“), aluzija na narodnu pjesmu (Ismet Rebronja: „Tajni jezik“, Milosav Tešić: „Kupinovo“), aluzija na religiozne tekstove (Rajko Petrov Nogo: „Iz pazuva boga“), aluzija na dječije stihove (Miroslav Cera Mihailović: „Pà‘).

Još izraženija je dominacija slobodnog stiha u antologiji Ulaznica (Dedović 2011), koja obuhvata sljedeću generaciju, rođenih 1960-tih i 1970-tih. Izuzev rijetkih prizvuka jednog silabičkog stiha (npr. kod Saše Jelenkovića: „Otmica je delo ljubavi“) i još rjeđe upotrebljavanih sporadičnih rima (npr. kod Vojislava Karanovića: „Sin zemlje“), u centru pažnje stoji apsolutno slobodni stih.

U vezi s tim je i vrlo znakovit zapis ${ }^{5}$ Stevana Tontića, $u$ kome on objašnjava pod kojim okolnostima se on vratio metrički strogom stihu:

Стеван Тонтић: Слободни и(ли) везани стих (одговор на питање проф. Ходела)

У мојим раним пјесничким збиркама доминирао је слободни, док са збирком Сарајевски рукопис (1993) почиње да превладава везани стих. Ипак, и даље сам писао и пишем, у знатној мјери, слободним стихом. Мислим да би се код мене могло говорити о својеврсној равнотежи између ових врста стихова. Ја их често и комбинујем.

У слободном стиху, у којем нема обавеза према метричкој схеми, одређеном броју слогова, рими, цезури итд., пјесник има више простора да се ритмички и реторички „размахне“ (рецимо, по узору на Волта Витмана, једног од великих пјесника слободног стиха). Неко је такве, слободне ритмове стихова назвао психолошким ритмовима. Они пружају осјећање неограничене слободе говора, а пјесницима је посебно до тога стало.

Ја сам, међутим, у савременој поезији често наилазио на одвећ „слободне“ стихове, испуњене личним (па и приватним) исповијестима, површним а опширним описима разних догађаја, тако да сам увидио вриједност класичне, строге форме у поезији. Форме која пјесника јаче умјетнички обавезује. И то сам увидио баш у тоталном ратном и животном расулу, рушењу свих постојаних облика, па и самог хуманог смисла егзистенције крајем деведесетих година. Осјетио сам потребу, јачу него прије, да своје лично искуство тога пријетећег расула уобличавам у чврсту форму везаног стиха, којом се указује на умјетничко и етичко достојанство пјесничког језика, насупрот језику неконтролисане, разуздане силе. Насупрот прилично необавезним причама и досјеткама, које могу бити и забавне. Тако сам написао много римованих пјесама, настојећи да избјегнем сваку звучну блискост са добро познатим и силно израубованим моделима римовања. Настојећи да се ослободим знаног призвука који многе римоване пјесме попримају од неаутентичног односа према традицији. Традицији која у њима неизбјежно „одјекује“.

У појединим мојим пјесмама римују се само поједини (не сви) стихови. Обично посљедњи с неким претходним стихом у строфи.

Допада ми се и непотпуно римовање, гдје се „римују“ звучно доста блиске или врло сличне ријечи које се ипак не подударају у пуној мјеру. Такав систем

5 E-mail autoru ovog teksta od 4.12.2020. 
римовања примјењује савремени њемачки пјесник Јан Вагнер, кога сам са задовољством превео на српски језик.

Ако се типична слабост поезије везаног стиха састоји у артифицијелности и „књишкости“ пјесничког израза, она се у пјесмама слободног стиха огледа у „развезаној“ нарацији коју на окупу не држи значајна идеја или мисао.

А права вриједност и употребљивост и слободног и везаног стиха види се, наравно, најбоље у врхунској поезији.

\section{Razlozi dominacije silabotonike u Rusiji}

Objašnjenja, zašto vezani stih u ruskoj književnosti tokom cijelog 20. vijeka a dijelom i poslije toga ima dominantnu ulogu, moraju bez sumnje ostati spekulativna. U prvoj liniji se odmah, međutim, pomisli na političke razloge. Ali upravo politički odnosi u Narodnoj Republici Poljskoj i u DDR-u pokazuju, da su sami politički faktori nedostatni za objašnjenje te pojave.

\subsection{Jezički razlozi}

2.1.1. Slavenski jezici, kao jako flektirajući jezici, imaju vrlo slobodan raspored riječi. To unutar jednog stiha omogućuje vrlo bogatu varijaciju rasporeda riječi prema ritmičkim i eufonijskim kriterijima, a da sintaksa pri tome ne zvuči „nezgrapno“. Ovu mogućnost posjeduje njemački npr. samo vrlo uslovno (a još ograničenije francuski i engleski).

2.1.2. Jezici sa jakim dinamičkim akcentom tendiraju na prirodan način ka tonskom (akcenatskom) pjesništvu u kome se metrički i jezički naglasci (iktusi) poklapaju (up. Küper 1988: 117). Ovo je, među četiri jezika koje posmatramo, skoro u potpunosti slučaj u ruskom i u njemačkom, koji, što je vrlo znakovito, samo u naznakama tendiraju ka silabičkoj tradiciji (koja razliku između naglašenih i nenaglašenih slogova niveliše metrički). Melodijski akcenat ${ }^{6}$, međutim, kakvog imamo u štokavskom, vodi u tonskom pjesništvu nužno ka iritacijama, pošto isti (naglašeni) vokali mogu biti različito intonirani (dugi ili kratki uzlazni, dugi ili kratki silazni). U štokavskom se ove otežavajuće okolnosti pojačavaju još i egzistencijom nenaglašene dužine. Otuda nije slučaj da su u 19. vijeku vršeni pokušaji da se piše kvantitirajućom silabotonikom (sa alternacijom dugih i kratkih slogova) prema starogrčkom uzoru. Štokavska silabotonika leži u naponskom polju između akcenatske i kvantitetske metrike i otuda valjda nikad nije mogla da se potpuno odomaći.

I mogućnosti rimovanja su melodijskim akcentom te dužinom masivno ograničeni: up. npr. pâs naspram päs, ili gòle-bòle, koji kao optički rimovani par ipak zvuči kao neprava rima.

O poljskom akcentu pišu Bartnicka et al. (2004: 78-79): „Akcenat riječi u poljskom se najčešće posmatra kao dinamički i vezan [...] Dinamički znači da je

${ }^{6}$ Melodijski akcenat ne ističe jedan glas samo pojačavanjem izgovora (dinamički princip), nego varijacijom visine tona (u tonskim jezicima poput kineskog) ili promjenama visine i putanjom tona (štokavski). 
naglašeni slog artikulisan sa većom akustičkom energijom. Istovremeno se uz to i u izvjesnoj mjeri ton uzdiže a slog se razvlači. Zato se akcenat u poljskom i kod nekih lingvista posmatra kao melodijski.“

2.1.3. Poljski, koji ima vezani (paroksitonski) akcenat, i njemački, čiji slobodni akcenat u jednoj riječi pada uvijek na isti slog (tj. ima nepokretan akcenat, upor. Báum, prema Báumes: drvo-drveta), imaju, za razliku od ruskog sa njegovim slobodnim i pokretljivim akcentom (up. мост, на мостý), manje mogućnosti da riječi u stihu metrički podese i da konačno tvore rime. Pogotovo poljski podliježe u vezi s tim snažnim restrikcijama: tako se muške rime mogu tvoriti samo od jednosložnih riječi. Izvjesnim ograničenjima podliježe i štokavski, koji od razvoja novoštokavskog dijalekta bilježi snažnu tendenciju naglašavanja prvog sloga.

Otuda npr. jampski stihovi sa stalnom cezurom imaju često drugi polustih koji je čisto trohejske prirode (up. npr. jampski jedanaesterac Jovana Dučića; Porobić 2010: 391).

2.1.4. U snažno flektirajućim jezicima kakvi su slavenski, mogućnosti gramatičkih rima su naspram njemačkog (kao i engleskog i francuskog) u osnovi veće. Najvažnije je pri tome to da sufiksi i nastavci mogu da nose naglasak 7 . Na njemačkom je to moguće, sa iznimkom nastavka -(l)ei (kao u riječi Liebelei), samo kod sufiksâ preuzetih iz stranih jezika: Praktikant(in), -Student, Veterinär, praktikabel, rigoros, spazieren itd. Pored posljednjih djelomično identičnih primjera (up. praktykántka, studéntka) poljski ima još neke daljnje mogućnosti (up. myślimy/robimy, półmiskami/gromadami), koje su, međutim, u poređenju sa ruskim ipak vrlo skromne (up. u ruskom glagolske sufikse, množinu imenica (ćirilički) $-b l,-u,-a / я(m a)$, nastavke lokativa na $-e,-u,-y,-a x / я x$, pridjevske nastavke duge i kratke forme, daktilske i hiperdaktilske rime na -áемый, áнная, -а́емая, -а́вшаяся, oblike za pripadnost poput -ич, -янин, -изм, itd.). Znakovito je već i to da sam pojam „gramatička rima“ u njemačkom ima sasvim drugo značenje nego u ruskom i poljskom, naime: „Rimovano povezivanje istog korijena, često i formi nastavaka iste riječi bez obzira na istozvučnost" (Wilpert 1989: 350-351; npr. bekleiden/kleidet).

2.1.5. Vrlo važan faktor je i statistički odnos između naglašenih i nenaglašenih slogova.

Dok je u ruskom u prosjeku naglašen svaki 3. $\operatorname{slog}^{8}$, u njemačkom pada naglasak na svaki drugi, a u štokavskom prosječno na dva i po sloga ${ }^{9}$ (prema Porobić 2010: 149). Ova činjenica je opet zavisna od prosječne dužine riječi, koja

7 U štokavskom postoje ovdje naravno ograničenja zbog akcenatskog pravila da su posljednji slogovi višesložne riječi uvijek nenaglašeni.

8 Prema Stankiewiczu (1960: 79) je odnos nenaglašenih i naglašenih slogova u ruskoj poeziji kao i prozi 2,8 .

9 U poeziji, dok u prozi taj broj oscilira između 2,79 (narodne pripovijetke) i 2,94 (umjetnička proza) (Porobić 2010: 149-150). 
u ruskom iznosi 2,2 sloga naspram 1,7 u njemačkom i 1,4 u engleskom ${ }^{10}$ (up. Fucks 1968: 80). Na ruskom govornom području je ovaj preduslov već u klasicizmu doveo do uvođenja pirihija. Tako npr. Lomonosov realizuje treći 3. iktus kod 4-stopnog troheja u 58,6\% slučajeva. U prvoj polovini 19. vijeka je treća stopa stiha naglašena samo još u 43,6\% slučajeva, a treći iktus u 4-stopnom jambu je kod mlađe generacije pjesnika u razdoblju od 1820-1840 realizovana tek samo još u $35 \%$ slučajeva (Gasparov 2000: 318).

Dvosložni metar zvuči otuda na ruskom u poređenju sa njemačkim mnogo mirnije, manje „dobošarski“", manje monotono (up. još Žirmunski 1925/1966: 80-85), a trosložni metri se mogu u skladu sa prirodnim tokom govora mnogo lakše praviti nego na njemačkom ili štokavskom (up. i Küper 1988: 118).

Uopšte se može ustanoviti da ruski u odnosu prema njemačkom, poljskom ili štokavskom raspolaže jednim jezičkim instrumentarijem, koji omogućuje bogatiju varijaciju i istovremeno silabotoniku koja je prilagođena prirodnom govoru.

\subsection{Estetski razlozi}

Aristotel (1458a) u svojoj Poetici određuje poeziju kao otklon od ,vladajuće”, „obične“ jezičke forme (tò parà tò kýrion), pri čemu se „neobični“ govor oblikuje primjenom stranih izraza. Kao „strano” (xenikòn) označava Aristotel glosu (npr. jednu riječ iz nekog drugog dijalekta), produžavanje (npr. produžavanje nekog sloga) i metaforu. S tim u vezi može se prozaizacija klasičnog vezanog stiha u lotmanovskom smislu shvatiti kao minus-postupak (Lotman 1970: 120-121), koji kao preduslov podrazumijeva egzistenciju pravilnog stiha i može ga se onda onoliko dugo upotrebljavati dokle postoji i svijest o otklonu od tog pravilnog stiha.

Moguće je, naravno, da se dominantna metrička tradicija ${ }^{11}$ u Rusiji, koja se uspostavila oko sredine 18. vijeka, još nije iscrpila, drugačije nego li je to slučaj na njemačkom, poljskom ili štokavskom govornom području ${ }^{12}$, gdje se vrlo izgrađeno pjesništvo može pratiti unazad sve do renesanse. Ovdje svakako treba misliti i o tome da jezičke datosti u ruskom ne samo da dozvoljavaju mnogostrana obnavljanja forme u okviru dominantne silabotonike (preferiranjem različitih metrova, u obliku polimetrije, varijacije dužine stiha, daktilskim i nepravim rimama, varijacijama forme strofe itd.), nego i razvoj jednog stiha koji se bez obzira na svoju pravilnost može proizvoljno približavati ritmu proze (nepodudaranjem između stope stiha i granice riječi, korišćenjem pirihija i spondeja, nepodudaranjem granice stiha i granice rečenične fraze, tj. sintakse stiha i sintakse rečenice, redukcijom uzvišeno zvučećih inverzija, sintaksom i leksikom svakodnevnog govora i sl.). Tako upada u oči npr. da se čak i u „neoklasičnoj“ sovjetskoj

10 O metričkim konzekvencijama ove raspodjele za engleski piše Küper (1988: 117): „U Engleskom dolaze često naglašene riječi u alternirajućem stihu češće nego svaka dva sloga, tako da oni nužno posjeduju ne samo jake (Hebungen), nego i slabe (Senkungen) slogove <... ““.

11 I u Rusiji ima jedna kratka faza u kojoj su pisani silabički stihovi. Ova će se versifikacija, koja se rasplamsala u drugoj polovici 17. vijeka, ipak brzo napustiti u korist silabotonike.

12 U štokavskom metrička tradicija počiva pri tome snažno na usmenom pjesništvu. 
epohi karakter 4-stopnog troheja mijenja: Dok je kod starijih sovjetskih pjesnika, rođenih do 1910-te prvi iktus realizovan još u 58,2\% slučaja, kod mlađe generacije, rođene poslije 1910-te, pada ovaj broj na 50,9\% (Gasparov 2000: 318). I produžavanje stihovnih redaka (удлинение строк) otpočinje još u sovjetsko doba, a razvija se u postsovjetsko doba još i dalje (isto: 309).

Jedna generalna procjena, dakle, da čvrsto pridržavanje klasičnog stiha nužno vodi ka estetskom gubitku, čini se problematičnom. Na razmišljanje navodi i činjenica da se ne pridržavaju silabotonike samo oficijelni sovjetski autori nego i većina opozicionih pjesnika — od Ahmatove do Mandeljštama i Brodskog ili Kibirova. A možda je moguće i to da je na zapadu Aristotelovski „neobični“ jezik pjesništva, koji se u „književnocentričnoj“ Rusiji 20. vijeka održao u lirici, preuzet od nekih drugih oblasti, npr popularne muzike.

\subsection{Političko-ideološki razlozi}

2.3.1. Već iz same skice razvoja ruskog stiha 20. vijeka proizilazi da je sovjetska politika čak i u jednom tako formalnom polju kao što je versifikacija izvršila duboki i dugoročni uticaj. Ovo vrijedi u prvoj liniji za „,neoklasičnu“ fazu Sovjetskog saveza 1935-1955. Cenzura, koja je već i prije 1935. onemogućavala štampanje slobodnih stihova npr. jednog Zabolockog ili Hljebnikova, u zenitu Staljinove ere zadire rigorozno i u kanonizaciju sadržaja i formi. Osnova za to jeste propagirano jedinstvo forme i sadržaja, koje vodi ka kritičkom stavu naspram svakog formalističkog eksperimenta ${ }^{13}$ :

Стиховедение начала века рассматривало стиховую форму (ритм, рифму и пр.) как самостоятельный эстетический возбудитель. Теперь такой взгляд осуждается как формалистический (Gasparov 2000: 269).

В критике утверждается мнение, что свободный стих несвойствен духу русского языка и противен традициям русской поэзии. Это получает даже идеологическое обоснование: именно в это время свободный стих становится господствующей стиховой формой в поэзии Западной Европы и Америки и для прямолинейных критиков превращается в символ упадочной буржуазной культуры, наглядное выражение распада личности (isto: 282).

Još je 1928. Majakovski u svom „Галопщик по писателям“ pisao prezirno o „pesnicima-emigrantima“ (поэты-эмигранты): „Sami troheji i jambovi“ („Одни / хорей да ямбы“; Gasparov 2000: 270). Sad se međutim cijela stvar okreće naglavačke: Troheji i jambovi postaju zaštitni znak realno egizistirajućeg socijalizma.

Ali se upravo Majakovski može uzeti i kao primjer toga da se slobodni stih, koji je u rano sovjetsko doba još deklarisan kao „pravovjerna forma proleterske umjetnosti““(„правомерной формой пролетарского искусства“; Orlicki 1995), ne izbjegava samo iz političkih nego i iz umjetničkih razloga. Jer futurista i proleterski uzor pjesnika (Majakovski) piše doduše po slobodnoj volji nesilabo-

13 O pitanju u kojoj je mjeri avangarda 30-tih godina svoj kraj doživjela zbog izvanestetskih razloga, pogledaj Hodel 2008. 
tonske (несиллаботонические) stihove, ali ipak ne piše konzekventno slobodne stihove.

U vezi s tim su vrijedni pomena i klasični stihovi Ahmatove, Cvetajeve, jednog Mandeljštama ili Pasternaka, koji su djelomično pisani „в стол“"14, tj. bez obzira na moguću cenzuru. Ova okolnost se do sada objašnjavala povezanošću ovih autora sa predsovjetskom kulturom i poetskom tradicijom. Pri tome se radi o argumentu koji se ponavlja i u odnosu prema opozicionim pjesnicima kasne sovjetske ere, čiji se dominantan stih isto tako malo razlikuje od oficijelnog pjesništva (Josip Brodski, Viktor Krivulin, Sergej Stratanovski, Jelena Švarc, Jurij Kublanovski, Olga Sedakova, Sergej Gandlevski i dr.). Time se dominantna silabotonika oba politička tabora, kako oficijelnog tako i inoficijelnog, može konačno tumačiti kao posljedica totalne kontrole.

Bez odbacivanja ovog argumenta, ostaje otvoreno pitanje da li politički razlozi nude dovoljno ubjedljivo objašnjenje. Jer upravo u prve dvije decenije 20. vijeka, kada se u zapadnoj Europi i SAD-u nametnuo slobodni stih, ostaje ruska silabotonika dominantna uprkos jednoj dalekosežno liberalnoj klimi. Pa ipak nesumnjivo je da je sovjetska država sve do svoga nestanka mogla vršiti masivni uticaj na književnost i cjelokupne njene formacije - preko tijela za cenzuru, časopisa i nagrada. Tako Orlicki (1995) piše o slobodnom stihu:

Поэты, плодотворно и интересно работавшие в середине века с этой формой стиха - Д. Хармс, С. Нельдихен, В. Мазурин, Г. Оболдуев - оказались практически вычеркнутыми из живой литературы. Только в конце 1950-х начале 60-х годов свободный стих вновь выходит из подполья. Правда, ненадолго: официальный идеологический запрет с него, вроде бы, снят, однако продолжает действовать ничуть не менее строгий редакторский, вкусовой барьер. Редкие публикации свободных стихов В. Бурича, В. Солоухина, К. Некрасовой, Н. Рыленкова сопровождались резко отрицательной официальной критикой - несмотря даже на то, что в те же годы, не афишируя этого, публикуют свои „опыты верлибра“ такие мэтры советской поэзии, как Н. Ушаков, И. Сельвинский, К. Симонов, Е. Винокуров, Д. Самойлов, Б. Слуцкий, А. Вознесенский, Л. Озеров, О. Шестинский, В. Боков, А. Яшин - как видим, авторы самых различных творческих ориентаций.

Ne samo u neoklasičnim alternativnim strujanjima poput neoakmeizma (Arsenije Tarkovski, Bela Ahmadulina, Aleksandr Kušner, Jevgeni Rejn pa do Josipa Brodskog i Viktora Krivulina) ili neobaroka (Ivan Ždanov, Jelena Švarc, Aleksandr Jerjomenko, Vitalij Kaljpidi) ostaje silabotonika dominantna. Njena neupitna pozicija predstavljala je u godinama 1960-1980 i osnovu za postmodernističko pjesništvo. U tom pogledu se i silabičkotonski stih jednog Prigova, Kibirova ili Limonova objašnjava manje težnjom ka kontinuitetu a više radikalnom ironizacijom forme. Klasični metar, bilo sovjetski 3-stopni anapest (Kibirov) ili puškinovski 4-stopni jamb (Prigov), izbija u ovim postmodernističkim tekstovima poput palimpsesta i evocira kao prepoznavajući predložak jednu

14 Pisanje „za sto“ - praksa sovjetskih pisaca da nešto pišu sa sviješću o tome da zbog cenzure nema nade da će se to i objaviti. 
decidiranu distancu. Moskovski konceptualisti ostaju time u formalnoj sjenci sovjetske (klasične) versifikacije, stvaraju međutim istovremeno i važan preduslov za razvoj slobodnog stiha: oni od klasične versifikacije prave jednu markiranu formu.

2.3.2. Poseban aspekt sovjetskog doba osvjetljava Mihail Gronas (2012) u svom članku „Napamet: o mnemotehničkoj egzistenciji stiha“ („Наизусть: о мнемоническом бытовании стиха"). On ovdje predstavlja kako je kultura učenja napamet iz 19. vijeka ne samo na zapadu nego i u Rusiji (između ostalog i od strane Lava Tolstoja) podvrgnut oštroj kritici. Ovaj stav su najprije preuzeli i mladi revolucionari:

В первые годы после революции большевистские педагоги, наследуя реформаторам XIX века, предсказуемо ополчились против механического заучивания и объявили запоминание наизусть формой буржуазного гнета. Но в начале 1930-х годов, с упрочением государственного аппарата и усилением идеологического контроля над образованием, заучивание поэзии было заново открыто в качестве эффективного инструмента внушения советским детям чувства национальной и идеологической общности.

Ovu školsku praksu shvata Gronas kao sredstvo opšte indoktrinacije:

Запоминаемый текст, следовательно, может восприниматься как когнитивное вторжение, чужой голос, поселившийся в сознании выучившего, и, следовательно, как потенциальный плацдарм для индоктринации или „идеологической обработки““.

Ovdje Gronas pominje i to da je ova praksa bila od koristi ne samo za širenje ideološki poduprijetih nego i ,neprijateljskih“ sadržaja.

Ovdje se pomisli odmah npr. na pjesme Ahmatove. Važno je pri tome da u oba slučaja „mnemotehnička egzistencija poezije“ (мнемоническое бытование поэзии) podržava klasičnu pjesničku formu, koja se može brže i dugotrajnije učiti napamet nego slobodni stih.

2.3.3. Aleksandar Skidan ${ }^{15}$ postavlja neoklasicističke tendencije sovjetskog vremena u jedan širi kontekst, kada, oslanjajući se na Giorgioa Agambena (2000), slobodni stih objašnjava u kontekstu zapadnjačke sekularizacije, a sovjetsku poetsku praksu kao formu re-sakralizacije.

Čak i ako se pojam sakralnog ovdje može primijeniti samo uslovno, ostaje neupitno da kult ličnosti, koji je pod Staljinom dosegao naročite razmjere, ide ruku pod ruku sa izraženom ritualnosti i pobožnosti i da je silabotonika u širem smislu dio ovog opšteg državnog ponašanja. A ovdje je mogao i kult Puškina igrati takođe ništa manju ulogu.

2.3.4. U širem smislu shvaćeno može se misao o re-sakralizaciji primijeniti i na ona tumačenja ruske kulture, koja u njoj u prvi plan guraju duhovno, ira-

15 E-mail autoru ovog teksta od 4. Maja 2016, objavljen u Hodel (2018: 238) 
cionalno i religiozno naspram materijalnosti, racionalnosti i ekonomičnosti zapada. Kao što je poznato vrednovanje ovih nastojanja je svakako dosta različito: Nasuprot predstavi o regresiji i restrikciji (npr. u День опричника Vladimira Sorokina) stoji pozitivno konnotiran konzervativizam (npr. u djelu Санькя Zahara Prilepina).

S ove tačke gledišta posmatrano proizilazi da je i sovjetska epoha u kontinuitetu sa razvojem ruske kulture i državnosti uopšte. Da li se ovdje isključivo definiše Rusija u razgraničenju prema zapadu ili je djelomično i obratno, makar u doba nakon 2. Svjetskog rata, to ostaje otvoreno pitanje - i u odnosu na slobodni stih.

\section{LITERATURA}

Agamben 2000 - Agamben Giorgio. Il tempo che resta. Un commento alla Lettera ai romani. Torino: Bollati Boringhieri, 2000.

Aristoteles 1994 - Aristoteles. Poetik. Griechisch/Deutsch. Stuttgart: Reclam, 1994.

Bartnicka et al. 2004 - Bartnicka Barbara, Hansen Bjorn, Klemm Wojtek, Lehmann Volkmar, Satkiewicz Halina. Grammatik des Polnischen. München: Verlag Otto Sagner, 2004.

Breuer 1991 - Breuer Dieter. Deutsche Metrik und Versgeschichte. München: Wilhelm Fink Verlag, 1991.

Davidov 2013 - Давыдов Данила. «Приключение верлибра (Фестиваль как повод взглянуть на свободный стих со всех сторон)». http://magazines.russ.ru/arion/2013/3/21d.html

Dedović 2011 - Dedović Dragoslav. "Ulaznica. Ali za šta?/Eintrittskarte. Doch worfür?". Srbija: Panorama pesnišstva 21. veka. Wien, Zrenjanin: Drava, 2011: 350-352.

Fucks 1968 - Fucks Wilhelm. Nach allen Regeln der Kunst. Diagnosen über Literatur, Musik, bildende Kunst - die Werke, ihre Autoren und Schöpfer. Stuttgart: DVA, 1968.

Gasparov 2000 - Гаспаров Михаил. Очерк истории русского стиха. Москва: Фортуна Лимитед, 2000.

Gomringer 1972 - Gomringer Eugen. (Hg.). Konkrete poesie. Stuttgart: Philipp Reclam Jun., 1972.

Hodel 2008 - Hodel Robert. "Der Sozialismus als ästhetische Innovation? Zu Ostrovskijs Kak zakaljalas' stal' und Hermlins Die Kommandeuse". Brehmer Bernhard, Fischer Katrin, Krumbholz Gertje (Hg.). Aspekte, Kategorien und Kontakte slavischer Sprachen. Festschrift für Volkmar Lehmann zum 65. Geburtstag. Hamburg: Verlag Dr. Kovac, 2008: 221-235.

Hodel 2011 - Hodel Robert. Hundert Gramm Seele / Deset deka duše. Serbische Poesie aus der zweiten Hälfte des 20. Jahrhunderts. Herausgegeben, übertragen, kommentiert, mit Biographien und Bibliographien von 28 Dichtern. Leipzig, 2011.

Hodel 2015 - Hodel Robert. Vor dem Fenster unten sind Volk und Macht/3а окном внизу народ и власть. Russische Poesie der Generation 1940-1960. Herausgegeben, übertragen, kommentiert, mit Biographien von 31 Dichtern. Leipzig, 2015.

Hodel 2018 - Hodel Robert. «Поэтическая форма как фактор идентичности». Stahl Henrike, Evgraškina Ekaterina (Hg.). Субъект в новейшей русскоязычной поэзии - теория и практика (Neue Lyrik: Interdisziplinäre und Interkulturelle Studien, Band 4). Berlin 2018: 219-240.

Hodel 2019 - Hodel Robert. Sie ging durch Russland... / Шла по Pоссии... Russische Poesie der Generation 1960-1980. Herausgegeben, übertragen, kommentiert, mit Biographien und Bibliographien von 28 Dichtern. Leipzig, 2019.

Küper 1988 - Küper Christoph. Sprache und Metrum. Tübingen: Max Niemeyer Verlag, 1988.

Lotman 1970 - Лотман Юрий. Структура художественного текста. Москва: Искусство, 1970.

Nietzsche 1960 - Nietzsche Friedrich. Werke in 3 Bdn. Hg. von K. Schlechta. München: Carl Hanser, 1960. 
Orlicki 1995 - Орлицкий Юрий. «Русский верлибр: мифы и мнения». Арион 3 (1995): 8592. http://magazines.russ.ru/arion/1995/3/monolog1.html

Porobić 2010 - Porobić Sead. Ispitivanje razvoja versifikacije u poeziji Bosne i Hercegovine. Zagreb-Sarajevo: Naklada Zoro, 2010.

Pszczołowska 2001 — Pszczołowska Lucylla. Wiersz polski. Wrocław: Fundacja na Rzecz Nauki Polskiej, 2001.

Škreb/Stamać 1986 - Škreb Zdenko, Stamać Ante. Uvod u književnost. Zagreb: Globus, 1986.

Stankiewicz 1960 - Stankiewicz Edward. "Linguistics and the study of poetic language". Sebeok Th. (ed.). Style in language. Cambrigde (Mass.) - New York: MIT Press Massachussetts Institute of technology - John Wiley \& sons, 1960: 69-81.

Wagenknecht 2007 - Wagenknecht Christian. Deutsche Metrik. Eine historische Einführung. München: C. N. Beck, 2007.

Wilpert 1989 - Wilpert Gero von. Sachwörterbuch der Literatur. Stuttgart: Kröner, 1989.

Žirmunski 1925/1966 - Žirmunskij Viktor. Introduction to Metrics: The Theory of Verse. The Hague: Walter de Gruyter \& Co, 1926/1966.

\section{REFERENCES}

Agamben 2000 - Agamben Giorgio. Il tempo che resta. Un commento alla Lettera ai romani. Torino: Bollati Boringhieri,, 2000.

Aristoteles 1994 - Aristoteles. Poetik. Griechisch/Deutsch. Stuttgart: Reclam, 1994.

Bartnicka et al. 2004 - Bartnicka Barbara, Hansen Bjorn, Klemm Wojtek, Lehmann Volkmar, Satkiewicz Halina. Grammatik des Polnischen. München: Verlag Otto Sagner, 2004.

Breuer 1991 - Breuer Dieter. Deutsche Metrik und Versgeschichte. München: Wilhelm Fink Verlag, 1991.

Davidov 2013 - Davydov Danila. "Priklyuchenie verlibra (Festival' kak povod vzglyanut' na svobodnyj stih so vsekh storon)". http://magazines.russ.ru/arion/2013/3/21d.html

Dedović 2011 — Dedović Dragoslav. „Ulaznica. Ali za šta?/Eintrittskarte. Doch worfür?“. Srbija: Panorama pesništva 21. veka. Wien, Zrenjanin: Drava, 2011: 350-352.

Fucks 1968 - Fucks Wilhelm. Nach allen Regeln der Kunst. Diagnosen über Literatur, Musik, bildende Kunst - die Werke, ihre Autoren und Schöpfer. Stuttgart: DVA, 1968.

Gasparov 2000 - Gasparov Mihail. Ocherk istorii russkogo stiha. Moskva: Fortuna Limited, 2000.

Gomringer 1972 - Gomringer Eugen. (Hg.). Konkrete poesie. Stuttgart: Philipp Reclam Jun., 1972.

Hodel 2008 - Hodel Robert. "Der Sozialismus als ästhetische Innovation? Zu Ostrovskijs Kak zakaljalas' stal' und Hermlins Die Kommandeuse". Brehmer Bernhard, Fischer Katrin, Krumbholz Gertje (Hg.). Aspekte, Kategorien und Kontakte slavischer Sprachen. Festschrift für Volkmar Lehmann zum 65. Geburtstag. Hamburg: Verlag Dr. Kovac, 2008: 221-235.

Hodel 2011 - Hodel Robert. Hundert Gramm Seele / Deset deka duše. Serbische Poesie aus der zweiten Hälfte des 20. Jahrhunderts. Herausgegeben, übertragen, kommentiert, mit Biographien und Bibliographien von 28 Dichtern. Leipzig, 2011.

Hodel 2015 - Hodel Robert. Vor dem Fenster unten sind Volk und Macht/3а окном внизу народ и власть. Russische Poesie der Generation 1940-1960. Herausgegeben, übertragen, kommentiert, mit Biographien von 31 Dichtern. Leipzig, 2015.

Hodel 2018 - Hodel Robert. "Poeticheskaya forma kak faktor identichnosti". Stahl Henrike, Evgraškina Ekaterina. (Hg.). Sub"ekt v novejshej russkoyazychnoj poezii-teoriya i praktika (Neue Lyrik: Interdisziplinäre und Interkulturelle Studien, Band 4). Berlin 2018: 219-240.

Hodel 2019 - Hodel Robert. Sie ging durch Russland... /Шла по Pоссии... Russische Poesie der Generation 1960-1980. Herausgegeben, übertragen, kommentiert, mit Biographien und Bibliographien von 28 Dichtern. Leipzig, 2019.

Küper 1988 - Küper Christoph. Sprache und Metrum. Tübingen: Max Niemeyer Verlag, 1988. Lotman 1970 — Lotman Yurij. Struktura hudozhestvennogo teksta. Moskva: Iskusstvo, 1970. 
Nietzsche 1960 - Nietzsche Friedrich. Werke in 3 Bdn. Hg. von K. Schlechta. München: Carl Hanser, 1960.

Orlicki 1995 - Orlickij Yurij. "Russkij verlibr: mify i mneniya". Arion 3 (1995): 85-92. http:// magazines.russ.ru/arion/1995/3/monolog1.html

Porobić 2010 - Porobić Sead. Ispitivanje razvoja versifikacije u poeziji Bosne i Hercegovine. Zagreb-Sarajevo: Naklada Zoro, 2010.

Pszczołowska 2001 — Pszczołowska Lucylla. Wiersz polski. Wrocław: Fundacja na Rzecz Nauki Polskiej, 2001.

Škreb/Stamać 1986 - Škreb Zdenko, Stamać Ante. Uvod u književnost. Zagreb: Globus, 1986.

Stankiewicz 1960 - Stankiewicz Edward. "Linguistics and the study of poetic language". Sebeok Th. (ed.). Style in language. Cambrigde (Mass.) - New York: MIT Press Massachussetts Institute of technology — John Wiley \& sons, 1960: 69-81.

Wagenknecht 2007 - Wagenknecht Christian. Deutsche Metrik. Eine historische Einführung. München: C. N. Beck, 2007.

Wilpert 1989 - Wilpert Gero von. Sachwörterbuch der Literatur. Stuttgart: Kröner, 1989.

Žirmunski 1925/1966 - Žirmunskij Viktor. Introduction to Metrics: The Theory of Verse. The Hague: Walter de Gruyter \& Co, 1926/1966.

Роберт Ходель

\section{СТИХОТВОРНАЯ ФОРМА. СОПОСТАВИТЕЛЬНЫЙ ВЗГЯД НА РУССКУЮ ЛИРИКУ ХХ ВЕКА}

Резюме

Данная работа посвящена вопросу, почему рифмованный стих сохранился в России, в отличие от европейской и американской поэзии, на протяжении всего $\mathrm{XX}$ века и стал доминирующей стихотворной формой. При этом мы сначала сопоставим развитие русской поэзии с немецкой, польской и сербской лирикой, а потом проанализируем языковые, эстетические и политические причины, повлиявшие на возникновение этой разницы.

Ключевые слова: рифмованый стих, верлибр, лингвистика стиха, развитие стихотворной формы, русская поэзия, сербская поэзия, немецкая поэзия, польская поэзия. 